\title{
Integration of 21st Century Skills: An Innovative Alternative Practice in the Teaching \& Learning of Islamic Education
}

\author{
$1^{\text {st }}$ Gamal Abdul Nasir Zakaria ${ }^{1}, 2^{\text {nd }}$ Norkhairiah Hashim ${ }^{2}, 3^{\text {rd }}$ Aliff Nawi ${ }^{3}, 4^{\text {th }}$ Salwa Mahalle4 \\ \{gamal.abdulnasir@gmail.com\}
}

\author{
Sultan Hassanal Bolkiah Institute of Education, Universiti Brunei Darussalam, Brunei ${ }^{1,4}$, Halalan \\ Thayyiban Research Centre, University Islam Sultan Sharif Ali, Brunei ${ }^{2}$, School of Education \& Modern \\ Language, Universiti Utara Malaysia, Malaysia ${ }^{3}$
}

\begin{abstract}
The development of information and communication technology has leads to a revolution in the education sector. The usage of conventional methods starts to be integrated with media and technology material. Mobile devices users for example iPad, tablet and Pocket PC users have also increased from time to time. This article attempts to explore the potential of mobile technology usage in education. Issues and challenges faced by the users are also identified to discover how the problems can be solved. The study uses qualitative method through literature study and document analysis. The study has also established that there are a lot of main challenges that need to be emphasized in mobile technology usage in education. Some of them are application developer, type of application, model instructional design choice and target group that will use the developed material. The conclusion is, the usage of mobile technology in education is still in early phase and needs to be improved from time to time to ensure the effectiveness of this method in the future.
\end{abstract}

Key words: 21 st century skills, innovation, teaching and learning Islamic education

\section{Introduction}

Discussion on the skill requirements of the 21 st century has already begun globally and one of the question whether he situation that allows students to gain learning experiences term 'high performance learning experiences' and the answer to this question is the need for teachers who are not just counselors who care and inspired by students and even teachers enthusiasm internally and support externally to fully accept the challenges of teaching and learning to a higher level (Bernie and Charles, 2009).

However, the effectiveness of teaching and learning practices are less entertaining where the teacher are more conveying information rather than letting their student to actively participate in education activity. This makes teaching and learning scenarios is quite disappointing because there is a gap that causes the learning process to be passive. Students should be a player rather than a spectator in the classroom. The question is, what are the initiative taken by the teachers to transform education in the 21st century? Bernie and Charles (2009) stated the importance of student-centered learning to develop the essential skills required in the 21 st century. 21 st century skills that include elements of communication skills, collaboration, 
self-regulation, construction of knowledge, the use of ICT, problem solving and innovation (www.itlresearch.com) is very important and should be shared by all students, but otherwise should be integrated with the teaching and learning skills will result in the unlikely highlighted by the students. If this situation is allowed to persist and certainly does not warrant the establishment of skills in students while students have the knowledge, abilities, and potential low ground.

This is a great challenge to anyone who holds a practicing teacher where the application or the application of 21 st century skills in the teaching and learning process should not only focus on public education and even in implementing Islamic education is also very necessary to be more in line with the era of globalization because this practice is a reform or an innovation that combines a variety of skills in the process of educating and learning Islamic education and if these efforts can be implemented properly, it can stimulate students to collaborate, communicate and also maintain an interest in the subject of Islamic education and even the main purpose which is to develop the overall skills of the 21 st century.

Therefore, it is important that this first research was carried out to identify whether the matters should be considered especially the teaching and learning process that can stimulate the skills in 21 st century's students. To undertake this study was to observe whether there are another needs to fill the process in teaching and learning until it gave an affect and meaningful to students who are not just focused on give the knowledge but also to build the skills in students merely seeks to create a generation that capable and skilled to deal with various situations and challenges in the 21 st century.

\section{Concepts For The 21st Century Skills}

Finesse is a competency that is very important and needs to be realized in each individual student to provide and prepare for an empowered society generation or advanced and competitive to face the 21 st century. Reality today, purely academic graduation without significant proficiency principle cause difficult students to apply the knowledge that is obtained in the nature of work. (Bernie and Charles 2009). This clearly proves that skills agenda is a necessity that should be made to each individual student in order to generate quality human model well as increased momentum human civilization and development of the State.

21 st century skills in education today in the same time also increasingly debated and felt very necessary because of the advantage of covering a wide range of information skills and practice in the life and career, including accountability and productivity. Elements of $21 \mathrm{st}$ century skills is a summary of the most comprehensive and up is expected to produce students who are critical thinkers, problem solvers, capable of making decisions, creative, innovative, competent in media and information technology, as well as possess strong leadership, its flexibility and so on. All of these skills are supported by a number of systems that encourage students to build 21 st century skills that atmosphere or learning environment, standards and assessments, curriculum and instruction, and professional development. (The Partnership for 21st Century Skills: 2009) on the skill requirements of the 21 st century has already begun globally and one of the question whether he situation that allows students to gain learning

\subsection{Dimensions Of 21st Century Skills}


There are various initiatives that have been undertaken by the specialist research institutions in determining the dimensions of 21 st century skills that should be considered while outlining the goals we want to achieve and what are the pedagogical issues and things that need to be done efficiently repair especially related to the dimension of the 21 st century skills.

ITL Research (Innovative Teaching and Learning Research, 2011), which consists of advisers and expert education from various organizations around the world and Microsoft Partners in Learning is one of the research organization that has put the six dimensions of the following as of 21 st century skills that are absolutely required by the generation of students in this age which are knowledge construction, collaboration, communication, problem solving and innovative, use of ICT as well as self-regulation. Efforts to introduce 21st century skills are intended to support innovative teaching practices that have relationship with the learning of the 21 st century, especially the student centered pedagogy capable of demonstrating to students the 21 st century skills in the work produced.

The six dimensions of 21st century skills are explained (Innovative Teaching and Learning Research2011) as follows:

\section{1) Collaboration}

Collaboration is an essential skill that should be available on each individual student where students are encouraged to work together when implementing the pairing activity or in groups, students will share the roles and responsibilities fairly as well as to encourage them to make substantive decision together and produce work with a sense of interdependence between each other. The completion of their tasks shall prove that there are planning made and are designed coherently and comprehensively together.

\section{2) Communication}

Communication skills are also very important skills despair which encouraged students to produce a longlasting communications or multi-modal, and are able to express the evidence supporting their words but also it is capable to design and express their speeches specific to a particular audience.

\section{3) Self-regulation}

This dimension must be owned by the students is based on their sensitivity to the learning goals and success criteria for the next association in completing assignments and students are able to plan and supervising their work and improve the quality of work based on the feedback received.

\section{4) Construction of knowledge}

This dimension is a dimension that able to hone students' determination to build knowledge not only to create information, to make the interpretation, analysis, synthesis and critical assessment and even train students to apply the knowledge. Construction knowledge should show an increase in the level of complex and multidisciplinary.

\section{5) Problem Solving and Innovation}

Students' ability to solve problems is also training (practice) efficiency in mind the challenges of this millennium. Nowadays, solving the real problems is a test and a challenge to the students to figure out what the best solution to solve any problems and encourage students to innovate in implementing solutions that they get.

\section{6) The use of Information and Communication Technology}

Information and Communication Technology is very much enthused by this modern generation as a medium of communication to gain knowledge very fast, users of ICT give an impression of comparative advantage with the development of technology nowadays. The use of ICT in teaching and learning should support and help learners construct knowledge and 
should be able to upgrade the level of understanding of a learner to produce ICT products for the facilitation of other internet users.

Looking at the six-dimensional 21 st century skills, these six-dimension is very important in order to build the students skills as a whole taking the needs of IT as well as the challenges of present's technology and innovation. Siti Faizatul and Razali (2012) on the fact, the uses of the technology actually can lead to facilitate the process of teaching and learning and help the teachers meet the challenges with the potential of improving our use of the latest technology. And the need of improve the knowledge from the basic to more complex of thinking to solve problems and make decisions. Problem solving skills means students are able to overcome the problems encountered in the process of learning as a vehicle to practice face greater problems in life. Similarly, with reference to the importance of communication, collaboration and selfcontrol with regard to the challenges of the relationship between students and the situation at hand, Rushita (2012) stated that effective communication has now become a necessity that can guarantee success in today's globalized world.

\subsection{The Importance Of 21st Century Skills In Teaching And Learning Islamic Knowledge}

In addition, Religious education provides students with religious knowledge and Science, in other words fardhu ain and fardhu kifayah, Islamic Educaion also should develop the students' skills for preparing the changes and the current progress of information and technology. This way of improving the students' skills is not only suitable for limited and specialized in general education even these efforts also can be made towards the Islamic education can be done even more effectively by improving the function and role of Islamic education to move toward the establishment of a skilled generation. It suited the effort that are being recorded within the framework curriculum SPN 21 which is to build lifelong learning skills and provide student with high value skills or marketable skills. (Deparment of curriculum development 2009:32)

Philosophy of islamic education is also stressed that islamic education should serve as a deployment experiences in the form of skills and technical knowledge to change from time to time as well as dissemination of experiences based on fixed values found in relegion and can be obtained from Al-Quran and Sunnah. Abdul Rahman Aroff and Zakaria Kasa, 1994).

Along with the era of globalization and the development of science education in the rapidly both in terms of systems, curriculum, pedagogical training colleges, infrastructure, and so coupled with the learning-oriented students who are now being radically popularized then we can assume that the students are able to certainly gain knowledge, experience, skills and values that can be applied as well to meet the government's aspiration to create a model of welleducated people, skilled and brilliant. Integrated educational and social development of technology is also becoming an important requirement in today's world of education to facilitate the students to interact, communicate, collaborate and accelerate the transmitting and receiving information.

So likewise with Islamic Education, Wahyudi (2011) states that according to Islamic law of human nature not only encourage people to study science and technology but also to develop and build a civilization. He added that Islamic Education is a conscious and deliberate ceremony in preparing students to recognize, understand and appreciate the faith, piety and noble in practicing Islam from its primary source of Qur'an and Hadith through the guidance of teaching, training and using experience. Through this guidance of teaching, training and using experience can grow the patterns that support the development of skills in students. 
How this proves that the scope of Islamic education that includes a mix of complementary aspects of each other which includes the harmony, the balance between the human relationship with Allah Subhanahu Wataala, human relationship with himself and the with other human beings and the environment (Lulu, 2011). It must also be noticed by most teachers of Islamic education that in the modern era and digital, any religious subject matter is not limited by adopting the methods of dogmatic, but students also will be critically questioned about Islamic education material in accordance with reality, and the reality of the environment and everyday life.

Other than that, to improve and enhance the civilization is very important to achieve a perfect life. By improving the civilization of a person's life or in other words the skill in managing their lives and their future. Anas bin Malik narrated about Prophet Peace Be Upon Him said: Which means: "Honor your children and improve their manners?" (Ibn Majah, 1954) This civilization is very much required by the religion of Islam, especially through education. Abdul Aziz Al Ghazuli (2000) stated that Imam Ibn Al Juzi emphasizes how religious education is the mysticism of the past to the human civilization.

Nowadays, life is competitive which require thinking skills other than knowledge based on (The Partnership for 21st Century Skills: 2009), living skills and career need to be supplied to students such as leadership and responsibility, productivity and accountability, flexibility and capability to adapt changes and has initiative and vision. There are various methods to form such skills among students, including encouragement to take responsibility and work effectively in a team to set goals or direction, then critically discuss solutions through effective interaction.

According to The Partnership for 21st Century Skills: 2009, skills and innovative learning is focused on the four skills of critical and creative thinking, collaboration and communication. These skills seem to involve the use of common sense or lead to the activity of thinking. It is undeniable that thinking is something commanded by Islam. There are more than 40 verses written in the Al Qur'an that urge people to use common sense to think, as in verse 76 of surah Al Baqarah, "With the meaning, "Do you not think?"

This verse clearly proves that the act of thinking is required in Islam as the ability to think, it will not only benefit the mundane but it encourages people to use common dab their creativity to embrace the quality of life and to strive for progress and to help the development of personality. In conclusion, collaborate and communicate well is considered a personality development and progress and improvement of person's innovative of living, as well as the start of the ability to think critically and creatively.

World development now also requires that each individual is capable in the field of information, media and technology. Thus, it is also one of the important things which are encouraged by Islam because these skills are one of the gifts and sources of knowledge granted by Allah. Islam is not a religion if narrow but it does not restrict the human intellectual to gain knowledge to walk in line with the progress of time is not the same as long as the conflict or stray from the path of Islam, "Every time they want to get out of Hellfire from anguish, they will be returned to it, and [it will be said], "Taste the punishment of the Burning Fire!" (surah Al Hajj 22)

Life in the 21 st century requires each student to be able to function in a variety of skills related to information, media and technology. According to (The Partnership for 21st Century, 2009) these skills is to engage the students' ability to access information and make their own assessment as well as the ability of students to conduct research through digital technology and use information and manage information effectively and efficiently, including the ability to make an analysis of the media and be able to make interpretation about it.

Among the significances of the 21 st century skills set in Islamic education are: 
1. Describe the educational model of a medium of teaching and learning which can promote student's ideas and improve critical and creative thinking.

2. Implement the solidarity, cooperative, partnership and solidarity.

3. Increase the affective student.

4. To promote awareness of and confidence in cooperation and teamwork skills.

5. Attract students towards the use of ICT to become more harmonized and applied.

6. Stimulate interest in the exploration of information.

7. Generate ideas and thoughts to the maximum effect.

8. The need for ethical standards a complete and comprehensive as it is important for the control of human beings to create a no magnanimity and sense.

9. Promote awareness of moral values in order to produce a generation that maintains the advantages and disadvantages of fighting for the truth and reject.

10. Develop spiritual harmony and the strength and development of the individual.

11. In addition to maintaining the moral and social responsibility to create a generation of individuals who are committed to the rules and principles.

12. In addition, building a wild spiritual master to build personal strength and durability.

\subsection{The Importance of Innovation in Teaching and Learning}

In an effort to meet the demands of marketable skills it requires the competence and wisdom for the teachers implement the teaching process optimally. However, teaching and learning should not overlook the role of the soul and spiritual aspects to complement the growth of human potential which is cohesive, balanced and comprehensive. (Noor Hisham, 2011)

Traditional lecture, which is dominated in this century that only involves the transfer of information and knowledge, or referred to as 'Passive Diffusion Model Of Knowledge Transfer' less stimulating cognitive abilities of students can even invite a more complex effect on the students, such as failure to give full attention and difficulty in remembering information. Learning should occur just as the teaching of a process that is ongoing as to promote effective learning, should be the primary focus is the determination of students in performing tasks and achieving desired outcomes. (Eilks and Byers, 2009).

Therefore an innovation of reform should be carried out immediately on teaching and learning, particularly in Islamic education by adopting strategies concentrating on students, apart from the usual lecture methods being used, the opportunity to discuss the activities of students in groups must also be performed for the sole purpose of enriching the learning experience, increase the students interactivity with the teachers adding with the latest technology that certainly motivates students and provides them with a sense of comfort. (Mac Arther and Jones, 2008)

However, Eilks and Byer (2009) have increased in this chapter that inovation in teaching should be enhanced and improved as well as certain modifications can be made. Various measures improve the atmosphere of active learning that can challenge student's understanding through approach learning problems which can stimulate them to solve meaningful, encouraged to exchange views on the appropriate solutions as well as to clarify their thoughts about the raised issues. (Anderson, 2007). Among the advantages of innovative in teaching and learning Islamic education:

1. Help increase student motivation.

2. Facilitate the teaching and learning process.

3. Help the students to develop their interactive skills. 
4. Help to improve long-term memory.

5. It's effectiveness to change the way of teaching and learning.

6. Make a fast progress and simplify the management of teaching and learning.

7. Stimulate the understanding, interest and mind through various senses.

8. Generate a strong understanding and build mental structures.

9. Create more interesting and more meaningful surrounding/environment.

10. Dissemination of information and communication science is more flexible and has many advantages.

11. Focusing on the students to help them to develop cognitive and social skills, personal development and social maturity.

12. Helping the students to have autonomy and control over their own choice, personal responsibility, encourage the involvement and participation of the students and the relationship between students.

13. Provide opportunities for students to reproduce the information and construct knowledge?

14. The student is required to create ideas and understanding through interpretation, analysis, synthesis and evaluation.

15. Improve the students' ability to demonstrate conceptual understanding and applying knowledge in different context and connection information from a variety of academic disciplines.

16. Is the main driver and the main focus of teaching and learning that will be key to making the students either of the intellectual development of their spiritual, physical, emotional and social.

17. Seeks to help students integrate new information with existing experience.

18. Stimulate the exploration of broad and dynamic knowledge.

Among others, the importance of innovation in teaching and learning Islamic education in particular is:

1. Saved active learning environment if it starts with an idea, a concept, cognitive conflict provoked, conflict with the idea of a new phenomenon, making the solution of course has great potential in providing updates to students' thinking.

2. Make changes to a student centered approach includes working in pairs or in groups of course have consequences that support collaborative and cooperative learning among students.

3. Realization of cooperative learning also provides excellent opportunities for students to interact and communicate with the skills essential for learning to be resilient and able to form a better understanding of a subject and a specific problem solving strategy. This approach can stimulate students to formulate ideas, communicate and defending opinions.

4. The use of Information Communication Technology as a tool to get information quickly and can immediately affect the mindset towards more competitive to the technological advances today.

What is essential in order to innovate the teaching and learning is the teachers' understanding of teaching and learning needs of a particular topic and appreciate the difficulties faced by students and reflect the business or practice of innovation has been done. 


\section{Application For The 21st Century Skills In Islamic Education}

Focus on the development of 21 st century skills into teaching and learning as a requirement for cross-curricular education has become an important agenda and is often mentioned in the world of education to this day. However, the opportunity to apply the learning skills of the 21 st century still seems limited while innovative teaching practices may only be practiced by a number of teachers, but the efforts of various parties have been carried out to improve the professionalism of teachers to implement innovative teaching and learning in the 21 st century in order to support and encourage lifelong learning. There are actually a lot of teaching practices that can be done to achieve a certain objective or goal. Pedagogical use of the right strategy and approach, the use of methods and techniques for accurate and systematic ways certainly also help teachers to implement the teaching and learning process more effectively.

There are also a lot of research on teaching and learning strategies that are proven effective by the appropriate theory. ITL research (2011) suggest a practical lesson called innovative teaching practices where this type of teaching is divided into three categories of materials that could spur 21 st century skills thus producing product based skills for the 21 st century student centered on pedagogy that enhances the power of learning to students such as the development of science, control and self-assessment skills, collaboration and communication skills. While the second category is the cross-classroom learning that is associated with the relevance of science to the solution of problems faced by the reality of the world today and the next three categories, namely the integration of ICT into pedagogy as a goal to support the learning of the course plays an important role as a tool that can broaden and deepen learning opportunities. The following description of the model (ITL research, 2011) will further clarify the relationship from an extension or widening where proven teaching practices such as innovative teaching has a very strong correlation with the results of the 21 st century learning skills as Figure 1.

Islamic education implementation issues in a strategic and effective was closely related to the issue of teaching pedagogy is applied during the process of knowledge transfer. to note is about the meaning of the concept of teaching and learning, teaching is a task activities undertaken jointly by teachers and students. lessons designed by teachers systematically using appropriate methods and techniques for creating an environment of $g$ allows the learning process. The learning outcomes of severe changes in abundance remained relatively the same in the form of explicit or implicit.
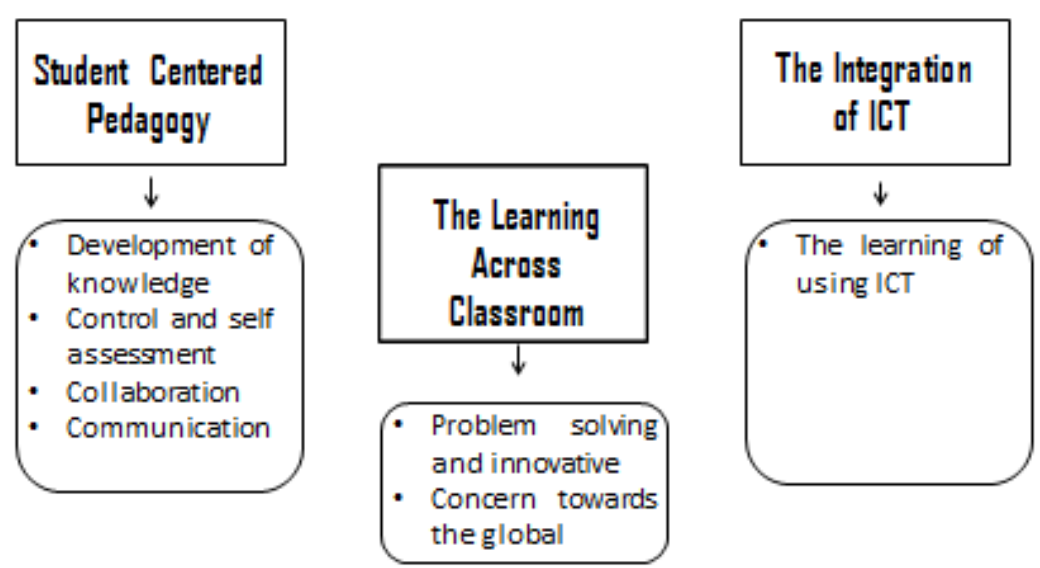

Figure 1. Innovative Teaching Practices 
Whereas teaching is a process of interaction between the participants of the learner and teacher so that there exists a process of gaining knowledge and understanding or the achievement of skills as well as the improvement of attitudes and confidence of the participant learner (NoorHisham, 2011)

Various teaching and learning strategies can be adjusted in order to integrate 21 st century skills with the right approach and combines a variety of methods and techniques without sacrificing the benefits of electronic technology and digital technology. The emergence of a variety of teaching and learning approach solely intended to meet the educational challenges of the 21 st century is rampant say. Among the approaches that incorporate a variety of methods and techniques of teaching and learning while integrating 21 ini century skills is like ( http://www.oum.edu.my/ ) The E Learning, Hybrid Learning Approaches, Approaches Blended Teaching and Learning, and the latest is known as Virtuol Teaching and Transformative Learning and Teaching and Learning.

However, the delivery system is dependent upon the evolution of the current sociotechnology as it also had to provide facilities in the form of group learning. Ministry of Energy, Water and Communications, Malaysia and Open University Malaysia (2004) in their study found that teachers encourage the integration of e-learning and conventional teaching mode for the integration of the two modes will further contribute to the teaching and learning more meaningful. It also proves that the teacher as the main pillar in practice the use of information and communication technologies and disseminating knowledge to the students. (Siti Faizatul and Razali, 2011).

According to the sketched diagram (The Partnership for 21st Century Skills: 2009) one of the systems that play the major role in generating students with 21 st century skills is the learning environment. When we talk about learning environment, it is often related with the effectiveness and it also depends on several aspects as stated by Kamarul Azmi and Halim Tamuri (2007) among the aspects that become the basis of the effectiveness.

Teaching and learning Islamic education is the content of the lesson, approaches , teaching and learning methods are good methods that can help students acquire the knowledge, skills and change attitudes and behavior, and to instill the desired value.

The teaching process is the most important agenda in the effort of implementing the KA21 because direct interaction of teachers and students takes place in order to transfer the knowledge and skills either through strategy, methods of diversity, techniques, activities, materials and media that are appropriate aims to provide more attractive incentives and activities in order to maintain attention and interest and make learning a fun atmosphere. It leaves a deep impression and continuous spirit of motivation within the hearts of the student. Among them:

Strategy: The strategy for effective teaching requires planning to achieve the goals and objectives of teaching and learning (Cole and Chal 1994) the main steps are the process of implementing, strengthening and maintaining skill and concentration of students.

Approaches: Either an interactive approach, an inductive or deductive approach, convergent or divergent, and so on.

Methods: Regular measures in order to achieve the learning outcomes in the short term (Syarifah Alawiyah Al Sagoof 1984)). Among the methods of problem-based learning, learning constructivism, co-operative learning, collaborative learning, and active learning.

Technique: The presentation of information is regarded as a teaching technique (Abdul Gahfara Mohd Din 2003). Meanwhile, according to Ahmad Mohd Salleh (2004) technique is a skill to run certain steps in the process of teaching and learning refers to small units in a method. Which technique is the application of appropriate KA21 group techniques, presentation, reflection, thinking (reflection), innovation, blended learning, and so on. 
Activities: Various activities can be carried out simply to provide opportunities for students to participate actively either through discussion, stretching, self-assessment (reflection) and so on.

Based on the concept and importance of 21 st century skills and innovative advantages as mentioned above may be attributed to that there are four types of income earned by a student from a good program of teaching and learning so that students can master the information, master the proficiency, develop their interest and attitude while four learning outcomes are already accounted for the cognitive, affective and psychomotor (Kamarul Azmi \& Halim Tamuri 2007)

\section{Conclusion}

Moving towards preparing a generation that is able to compete with challenges of the $21 \mathrm{st}$ century is actually a very heavy task and requires educators' resilience, especially in providing a medium and the teaching and learning environment that seeks to transform the culture of contemporary academic formation that is capable of enhancing efficiency of creating academic resilience.

\section{References}

[1] Abd Aziz S.H. Al Ghazuli. Ibnu Al Juzi: Al Imamul Murabbi, Wal Waeezul Baligh Wal 'Alimul Mutafannu. Darrul Qalam. Damsyik, 2000.

[2] Abd Rahim.Kemahiran Berfikir Merentasi Kurikulum: Pendekatan Pedagogi Dan Wawasan Pendidikan Bestari. Penerbit Fajar Bakti Sdn Bhd. Shah Alam, 1999.

[3] Abdillah dan Suriani. Faktor-Faktor Yang Mempengaruhi Tahap Penguasaan Kemahiran Komunikasi Di Kalangan Pelajar Tahun 4 Perdana Sarjana Muda Teknologi Serta Pendidikan. Kej. Awam, Kej. Elektrik, Kej. Jentera Dan Kemahiran Hidup) Di Universiti Teknologi Malaysia, 2011.

[4] Abdul Fatah. Pemikiran Keseluruhan Otak: Dalam Pengurusan Pendidikan Dan Kaitannya Dengan Kecerdasan Emosi (Emotional Intelligence - EQ). Utusan Publications dan Distributors Sdn Bhd. Kuala Lumpur, 1998.

[5] Abdul Rahman. Guru Sebagai Penyelidik. PTS Professional Publishing Sdn Bhd. Kuala Lumpur, 2009.

[6] Abdul Rahman Aroff dan Zakaria Kasa. Falsafah Dan Konsep Pendidikan. Fajar Bakti. Kuala Lumpur, 1994.

[7] Aliff Nawi \& Gamal Abdul Nasir Zakaria. Pembangunan \& Penilaian Portal iPBL dalam Kursus Pendidikan Islam di Politeknik Brunei. Jurnal Komunikasi, Malaysian Journal of Communication, 32(1), 2016, pp. 261-285

[8] Aliff Nawi, Gamal Abdul Nasir Zakaria, Norkhairiah Hashim \& Chua Chy Ren. Penilaian Kualiti Modul iPBL: Aspek Kesahan Dan Kebolehpercayaan. Journal of Quality Measurement and Analysis, 11 (2), 2015, pp. 1-10.

[9] Anderson dan Burns. Research in Classroom. The study of teachers, teaching and Instruction. Pergamon Press . USA, 1989. 
[10] Anderson, R.D. Inquiry as an organizing theme for science curricula. In:S.K. Abell \& N.G Lederman (Eds.), Handbook on research on science education (pp.807-830). Mahwah: Lawrence Erlbrum, 2007.

[11] Azlena dan Munir. Meningkatkan Potensi Minda. PTS Professional Publishing Sdn Bhd. Kuala Lumpur, 2007.

[12] Bernie dan Charles. 21st Century Skills: Learning For Life In our Time. . Jossey Bass Inc Publishers. San Francisco. California, 2009.

[13] Creswel. Educational Research. Planning, Conducting, And Evaluating, Quantitative and Qualitative Research. Fourth Edition. Pearson. USA, 2012.

[14] Dacey dan Lennon. Understanding Creativity. Jossey Bass Inc Publishers. San Francisco. California, 1998.

[15] Diane, Hanafi, Saw, Zubir, Lim dan Rozhan. Kesan Pembelajaran Konstruktivisme Berasaskan laman web di kalanagan pelajar fizik Universiti Sains Malaysia, 2003.

[16] Eilks \& Byers. Innovative Methods of Teaching and Learning Chemistry in Higher Education. RSC Publishing, 2009.

[17] Gardner. Changing Minds. The Art and Science of Changing Our Own And Other Peoples Minds. Harvard Business School Press. United States of America, 2004.

[18] Jabatan Perkembangan Kurikulum. Sistem Pendidikan Negara Abad 21 SPN21. Cetakan Pertama. Jabatan Perkembangan Kurikulum. Kementerian Pendidikan, 2009.

[19] Kamarul Azmi dan Halim Tamuri. Pendidikan Islam: Kaedah Pengajaran dan Pembelajaran. Penerbit UTM Press. Universiti Teknologi Malaysia, 2007.

[20] Lucas. Higher Education for Sustainability: Cases, Challenges, and Opportunities From Across The Curriculum. Routledge. New York, 2013.

[21] Mac Arthur, J.R \& Jones, L.L. A review of literature reports of clickers applicable to college chemistry classrooms. Chemistry Education Research and Practice, 9, 2008, pp. 187-195.

[22] Maggi \& Walkie. Problem Based Learning On line. Open University Press. England, 2006.

[23] Maria Langworth. 21st Century Learning: Learning that Matters Design, ITL research, 2013.

[24] Masyunizadan Zamri. Penyepaduan kemahiran Abad ke 21 Dalam Pengajaran Dan Pembelajaran Bahasa Melayu . Prosiding Seminar Pascasiswazah Pendidikan bahas Melayu dan Kesusteraan Melayu Kali Pertama 2013. UKM. Bangi, 2013.

[25] Metiri Group. enGauge 21st Century Skills, 2003.

[26] Ministry of Energy, Water and Communication, Malaysia and Open University Malaysia. Elearning Readiness in Malaysia 2004 Study is a joint initiative of the Ministry of Energy, Water and Communication, Malaysia and Open University Malaysia. Kuala Lumpur, 2004.

[27] Mohd Aliff Mohd Nawi \& Yusraini Ramlan. A Study on the Strategies and Practice of Teaching Among Trainee Teachers During Teaching Training. The Online Journal of Islamic Education, 2(1), 2014, pp. 1-6

[28] Mohd Aliff Mohd Nawi, Ezad Azraai Jamsari, Adibah Sulaiman \& Mohd Isa Hamzah. Development and evaluation of ning social network for teaching training online surveillance. Turkish Online Journal of Distance Education, 14(1): 2013, pp. 245-255.

[29] Mohd, N. M. A., Jamsari, E. A., Sulaiman, A. \& Hamzah, M. I. Development and evaluation of Ning Social Network for teaching traning online surveillance. Turkish Online Journal of Distance Education, 14(1), 2013, pp. 74-78.

[30] Nawi, A., Hamzah, M. I., Ren, C. C., \& Tamuri, A. H. Adoption of Mobile Technology for Teaching Preparation in Improving Teaching Quality of Teachers, International Journal of Instruction, 8(2), 2015, pp. 113-124. 
[31] Nawi, A., Hamzah, M.I. \& Abdul Rahim, A. A. Teachers Acceptance of Mobile Learning for Teaching and Learning in Islamic Education: A Preliminary Study. The Turkish Online Journal of Distance Education. 16(1), 2015, pp. 184-192.

[32] Nawi, M. A. M., Jamsari, E. A., Hamzah, M. I., Sulaiman, A. \& Umar, A. The impact of globalization on current Islamic education. Australian Journal of Basic and Applied Sciences, 6(8), 2012, pp. 74-78.

[33] Nawi, A., Hamzah, M. I., \& Sattai, S. A. A. Potensi Penggunaan Aplikasi Mudah Alih (Mobile Apps) dalam Bidang Pendidikan Islam. Online Journal of Islamic Education, 2, 2014, pp. 26 35

[34] Noor Hisham. Pengajaran dan pembelajaran : Penelitian Semula KonsepKonsep Asas Menurut Perspektif Gagasan Islamisasi Ilmu Moden. Kongres Pengajaran dan Pembelajaran UKM 2011. UKM . Bangi, 2011.

[35] Norazidawati. Penyepaduan Kemahiran Abad 21 dalam Pengajaran dan Pembelajaran Biology.Tesis Sarjana. University Kebangsaan Malaysia, 2011.

[36] Rushita. Communication Strategies And Collaboration Of Malaysian ESL Learne In Oral Interaction, 2012.

[37] Siti Faizatul dan Razali. Pengajaran dan Pembelajaran berasaskan Streaming Video bagi meningkatkan tahap kefahaman pelajar abad 21. Persidangan Kebangsaan Penyelidikan dan Inovasi Pendidikan dan Latihan Teknik dan Vokasional, 2011.

[38] United Nations Educational, Scientific And Cultural Organization. Youth and Skills Putting education to work. EFA Global Monitoring Report. UNESCO Publishing. France, 2012.

[39] United Nations Educational, Scientific And Cultural Organization. UNESCO Annual Report. Paris, France, 2013.

[40] Wee, Lynda, Kek dan Megan. Authentic Problem Based Learning . Prentice Hall. Pearson Education. Jurong, Singapore, 2002.

[41] Yahya dan Shahabudin. Kemahiran komunikasi dalam meningkatkan keyakinan diri pelajar satu tinjauan di kalangan ahli jawatankuasa kolej mahasiswa university teknologi Malaysia, 2010.

[42] Yang, S. C. Synergy of Constrctivism and Hypermedia from three constructivist perspectives, social, semiotic and cognitive. Educational Computing Research 24 (4), 2001, pp. 321-362. 